\title{
Nitrogen-Containing Compounds in the Scent Gland Secretions of European Cladonychiid Harvestmen (Opiliones, Laniatores, Travunioidea)
}

\author{
Günther Raspotnig • Miriam Schaider • \\ Petra Föttinger • Christian Komposch • Ivo Karaman
}

Received: 24 January 2011 /Revised: 1 May 2011 / Accepted: 7 July 2011 /Published online: 16 July 2011

(C) The Author(s) 2011. This article is published with open access at Springerlink.com

\begin{abstract}
The exocrine secretions from prominently developed prosomal scent glands in four species of the European laniatorean harvestman genus Holoscotolemon (Laniatores, Travunioidea, Cladonychiidae) were analyzed by gas chromatography - mass spectrometry. Two major alkaloidal compounds were detected: Nicotine accounted for more than 97\% of the secretion in Holoscotolemon jaqueti and $H$. oreophilum, whereas the chemically related nicotinoid alkaloid anabaseine was the major compound in H. lessiniense. In addition, a series of minor nitrogen-containing components was found, namely 3-(1-methyl-2-piperidinyl)-pyridine and anabasine, in $H$. jaqueti and $H$. oreophilum, and anabasine together with 2,3'-bipyridyl in $H$. lessiniense. By contrast, extracts of adult $H$. unicolor did not show any components. In one juvenile specimen of $H$. unicolor, however, low
\end{abstract}

G. Raspotnig $\cdot$ M. Schaider $\cdot$ P. Föttinger

Institute of Zoology, Karl-Franzens University,

Universitätsplatz 2,

8010 Graz, Austria

G. Raspotnig $(\bowtie) \cdot$ P. Föttinger

Research Unit of Osteology and Analytical Mass Spectrometry,

Medical University, University Children's Hospital,

Auenbruggerplatz 30,

8036 Graz, Austria

e-mail: guenther.raspotnig@uni-graz.at

C. Komposch

Institute of Animal Ecology and Landscape Planning,

ÖKOTEAM,

Bergmanngasse 22,

8010 Graz, Austria

\section{Karaman}

Department of Biology and Ecology, Faculty of Science,

University of Novi Sad,

Trg Dositeja Obradovica 2,

2100 Novi Sad, Serbia amounts of alkyl pyrazines (dimethyl-isobutyl- and dimethylisopentylpyrazines) were detected. Nitrogen-containing components previously were found in Sclerobunus robustus (an American travunioid harvestman), so scent gland-derived alkaloids may be widespread or even common in the Travunioidea. Alkaloids have not been reported for other opilionid scent gland secretions outside the Travunioidea, and we hypothesize that they may be the phylogenetically ancestral allomones in the Laniatores, having been reduced and replaced by a phenol- and benzoquinone-rich chemistry in the more derived grassatorean taxa.

Key Words Holoscotolemon · Alkaloids · Anabaseine · Nicotine $\cdot$ Chemical defense $\cdot$ Phylogenetics

\section{Introduction}

So-called "scent glands" (syn. defensive glands) are not only considered an important synapomorphic character of all harvestmen (Opiliones), but also represent by far the largest exocrine system in this arachnid order. Generally, these glands constitute paired sacs in the opilionid prosoma, opening onto the body surface via one large orifice ("ozopore") on each of the lateral margins of the carapax dorsal to the coxae of legs I or II. Their main biological role is thought to be predator defense (e.g., Martens, 1978), but scent glands also are sites of production of antimicrobial agents (e.g., Fieser and Ardao, 1956) or, in certain species, may emit pheromones (Holmberg, 1986; Machado et al., 2002). Moreover, opilionid scent glands are the sources of a diversity of rare natural products, and the chemistry of their secretions is characteristic for specific opilionid groups. For example, the secretions of Cyphophthalmi are complex and contain specific blends of naphthoquinones and methyl 
ketones (Raspotnig et al., 2005; Jones et al., 2009). Hitherto known secretions of the Palpatores include acyclic ketones, alcohols, and aldehydes, present in some sclerosomatid Eupnoi (Blum and Edgar, 1971; Meinwald et al., 1971; Jones et al., 1976, 1977; Ekpa et al., 1985), and naphthoquinones reported from one species of phalangiid Eupnoi (Wiemer et al., 1978). Only one study is available on scent gland secretions of the Dyspnoi, demonstrating the presence of naphthoquinones, methoxy-naphthoquinones, and anthraquinones in the scent glands of a nemastomatid species (Raspotnig et al., 2010). However, with respect to the number of species investigated, secretions of the mostly tropical Laniatores appear to be best studied. Laniatorean secretions are chemically distinct from the secretions of cyphophthalmids and palpatoreans, and specific patterns of phenols and benzoquinones have been demonstrated from a growing number of species since the 1950s (e.g., Estable et al., 1955; Eisner et al., 1971, 1977, 2004; Roach et al., 1980; Hara et al., 2005; review by Gnaspini and Hara, 2007; Shear et al., 2010a,b; Pomini et al., 2010; Föttinger et al., 2010). Essentially, nearly all published studies deal with representatives of groups of more-derivative Laniatores. Thus, the current knowledge on laniatorean secretions is strongly biased in favor of the Grassatores. The chemistry of scent gland secretions in the Insidiatores - a second, more basal laniatorean group - is almost unknown, but is crucial for a consistent picture of opilionid scent gland chemistry. Only one example of insidiatorean chemistry has been published so far (Ekpa et al., 1984), revealing a series of completely aberrant components from an American travunioid species, Sclerobunus robustus. These compounds include terpenes, such as bornyl esters, camphene, and limonene, and two alkaloids, namely N,N-dimethyl- $B$ phenylethylamine and the tobacco alkaloid nicotine.

One important and well recognized taxon within the Insidiatores is the Cladonychiidae (superfamily Travunioidea), including about 15 species in 5 extant genera (a 6th genus was described from Baltic amber by Ubick and Dunlop in 2005). While genera Cryptomaster, Erebomaster, Speleomaster, and Theromaster are restricted to the northern United States, an exclusively European clade is represented by eight species of Holoscotolemon, occurring from Western Europe to Romania and southwards to Serbia and Montenegro. As a first contribution to scent gland research in European Insidiatores, we here report on the scent gland chemistry of four species of Holoscotolemon, covering a representative part of European Cladonychiidae.

\section{Methods and Materials}

Collection of Species Specimens of Holoscotolemon jaqueti (Corti, 1905), H. lessiniense Martens, 1978, H. oreophilum Martens, 1978, and H. unicolor Roewer, 1915, were collected by hand under stones and litter, and from samples of leaf litter by means of a soil sifter. While $H$. jaqueti is a species with a disjunct South-East European and Carpathian distribution (Hungary, Slovakia, Romania, Ukraine, Bosnia and Hercegovina, Serbia), H. unicolor is restricted to the Eastern Alps (Austria, Slovenia, North Eastern Italy), and both $H$. lessiniense and $H$. oreophilum are local endemics of the southwestern Alps (Italy). Holoscotolemon oreophilum can be found in a small area in the Sea Alps/Alpes Maritimes and Ligurian Alps in Italy, and $H$. lessiniense inhabits the Monti Lessini close to the Lake Garda in the Southern Alps. The investigated material was collected in Serbia (H. jaqueti), Italy (H. oreophilum, H. lessiniense), and Austria (H. unicolor) (Table 1). For determination of the Holoscotolemon species, we used descriptions of Martens (1978). The material is stored in the collections of Ch. Komposch (Graz), G. Raspotnig (Graz), and I. Karaman (Novi Sad).

Extraction and Analysis of Secretions Scent gland secretion was obtained by whole body extraction of individuals in $150 \mu \mathrm{l}$ of hexane or ethyl acetate for about $30 \mathrm{~min}$ as previously described and standardized for other opilionids (Raspotnig et al., 2005, 2010). In total, 21 extracts were prepared, mostly extracts of single individuals (adults), but in some cases also pooled extracts (juveniles), as summarized in Table 1. Aliquots of extracts $(2 \mu \mathrm{l})$ were subject to gas chromatographic - mass spectrometric (GC-MS) analysis, using a Trace GC2000 coupled to a Voyager MS, both from Thermo (Vienna, Austria). The GC was equipped with a ZB-5MS fused silica capillary column $(30 \mathrm{~m} \times 0.25 \mathrm{~mm}$ i.d., $0.25 \mu \mathrm{m}$ film thickness, Phenomenex, Germany). Injection was splitless with helium (at $1.5 \mathrm{ml} / \mathrm{min}$ ) as carrier gas. The column temperature was programmed from $50^{\circ} \mathrm{C}$ (held for $1 \mathrm{~min}$ ) to $200^{\circ} \mathrm{C}$ at $10^{\circ} \mathrm{C} / \mathrm{min}$, and then to $300^{\circ} \mathrm{C}$ at $15^{\circ} \mathrm{C} / \mathrm{min}$. The ion source of the MS and the transfer line were kept at $170^{\circ} \mathrm{C}$ and $310^{\circ} \mathrm{C}$, respectively. Electron impact (EI) spectra were recorded at $70 \mathrm{eV}$.

Reference Compounds Authentic nicotine (mixture of $(R)$ and (S)-nicotine) for comparison of GC-MS data was purchased from Sigma (Vienna, Austria). As a reference for authentic anabaseine, we used anabasine (from Sigma, Vienna, Austria), which also contained a small amount of anabaseine (about 1\%).

Quantification of Secretion Components Determination of absolute amounts of nicotine in secretions are based on the integration of peak areas in the chromatograms, and comparisons to a calibration curve established for authentic nicotine. 
Table 1 Collection of Holoscotolemon-species and preparation of extracts

\begin{tabular}{|c|c|c|c|}
\hline Species & Location (co-ordinates, altitude) & Date & Extracts no. ${ }^{\mathrm{a}}($ Individuals) \\
\hline H. jaqueti & $\begin{array}{l}\text { Serbia: Ovčar-Kablar Gorge, } \\
\text { above Ovčar Banja } \\
\left(43^{\circ} 53^{\prime} \mathrm{N}, 20^{\circ} 11^{\prime} \mathrm{E}, 375 \mathrm{~m}\right)\end{array}$ & 20 Mai 2009 & 1754 (1 juv), 1755 (1+), M430 (1 juv) \\
\hline H. oreophilum & $\begin{array}{l}\text { Italy: Alpi Marittime, Coli de } \\
\text { Tende S Limonette }\left(44^{\circ} 09^{\prime} \mathrm{N} \text {, }\right. \\
\left.7^{\circ} 32^{\prime} \mathrm{E}, 1,475 \mathrm{~m}\right)\end{array}$ & 29 July 2010 & $2447(1$ ふ̊), 2448 (1 우) \\
\hline \multirow[t]{2}{*}{ H. lessiniense } & $\begin{array}{l}\text { Italy: Mt. Lessini, Monte Pasubio } \\
\left(45^{\circ} 46^{\prime} \mathrm{N}, 11^{\circ} 07^{\prime} \mathrm{E}, 760 \mathrm{~m}\right)\end{array}$ & 17 July 2009 & $\begin{array}{l}\text { M353 (1), M354 (1), } \\
\text { M355 (1), M356 (1운) }\end{array}$ \\
\hline & $\begin{array}{l}\text { Italy: Mt. Lessini, NNE Verona, } \\
\text { S Velo Veronese }\left(45^{\circ} 35^{\prime} \mathrm{N},\right. \\
\left.11^{\circ} 04^{\prime} \mathrm{E}, 920 \mathrm{~m}\right)\end{array}$ & 31 July 2010 & $2449(1$ ㅇ \\
\hline \multirow[t]{6}{*}{ H. unicolor } & $\begin{array}{l}\text { Austria: Carinthia, Villach, } \\
\text { Eichholzgraben }\left(46^{\circ} 38^{\prime} \mathrm{N},\right. \\
\left.13^{\circ} 50^{\prime} \mathrm{E}, 590 \mathrm{~m}\right)\end{array}$ & 5 April 2010 & 1935 (1우), $1936\left(1{ }^{\Uparrow}\right)$ \\
\hline & \multirow{3}{*}{$\begin{array}{l}\text { Austria: Styria, Graz, Maria Trost } \\
\left(47^{\circ} 06^{\prime} \mathrm{N}, 15^{\circ} 29^{\prime} \mathrm{E}, 445 \mathrm{~m}\right)\end{array}$} & 20 April 2010 & 1973 (1 juv), 1983 (3 juv) \\
\hline & & 25 April 2010 & 1995 (3 juv) \\
\hline & & 10 May 2010 & 2000 (2 juv), 2001 (2 juv) \\
\hline & $\begin{array}{l}\text { Austria: Styria, Aibl }\left(46^{\circ} 41^{\prime} \mathrm{N} \text {, }\right. \\
\left.15^{\circ} 13^{\prime} \mathrm{E}, 400 \mathrm{~m}\right)\end{array}$ & 27 June 2010 & 2127 (1 juv) \\
\hline & $\begin{array}{l}\text { Austria: Carinthia, Soboth, road } \\
\text { between Krumbach and Rothwein } \\
\left(46^{\circ} 81^{\prime} \mathrm{N}, 15^{\circ} 07^{\prime} \mathrm{E}, 1,000 \mathrm{~m}\right)\end{array}$ & 23 June 2010 & 2243 (1ㅇ), $2244\left(1 \delta^{\Uparrow}\right), 2245$ (1ㅇ) \\
\hline
\end{tabular}

${ }^{a}$ Refers to intern labelling of extracts

Scanning Electron Microscopy For scanning electron microscopy (SEM), specimens were fixed in Bouin, washed, dehydrated, air-dried, and mounted on aluminum stubs prior to sputter coating with gold (AGAR sputter coater, Gröpl, Tulln, Austria). Micrographs (SEM) were taken with a Philips XL30 ESEM (Philips/FEI, Vienna, Austria) at high vacuum mode and $20 \mathrm{kV}$ accelerating voltage.

\section{Results}

Chemical Identification of Extract Components GC-MS analyses of extracts of adult Holoscotolemon jaqueti, $\mathrm{H}$. oreophilum, and $H$. lessiniense revealed two major (components $\mathrm{A}$ and $\mathrm{E}$ ), and three minor compounds (components B, C, and D) (Fig. 1). All components were identified as pyridine alkaloids as outlined in the following and as summarized in Table 2.

Major Components Component A showed an EI-mass spectrum consistent with that of nicotine [3-(1-methyl-2pyrrolidinyl)-pyridine], exhibiting a molecular ion $\left(\mathrm{M}^{+}\right)$at a mass charge/ratio $(\mathrm{m} / \mathrm{z})$ of 162 , loss of a hydrogen atom $(\mathrm{m} /$ $z 161$ ), and a base ion at $m / z$ 84. The base ion corresponded to loss of the pyridyl moiety $\left(\mathrm{M}^{+}-78\right)$. Further fragments were observed at $m / z 133\left(\mathrm{M}^{+}-29\right)$ and $m / z 119\left(\mathrm{M}^{+}-43\right)$, both of which are reported as characteristic of nicotine, and correspond to losses of $\mathrm{C}_{2} \mathrm{H}_{5^{-}}$and $\mathrm{C}_{3} \mathrm{H}_{7}$-radicals from the molecular ion by different processes of rearrangement (Duffield et al., 1965). As a reference for comparison of GC retention, we used a racemic mixture of nicotine (nicotine has an asymmetric carbon atom in position 2 of the pyrrolidine-ring). The specific enantiomers, however, were not separable due to the chromatographic conditions used, and both enantiomers eluted as a single peak at RT= $10.54 \mathrm{~min}$, exactly matching the retention time of component A. Thus, we did not determine the chirality of nicotine from Holoscotolemon spp. So far, only the $(S)$-enantiomer is known to occur in nature.

The EI-mass spectrum of the second major component (E) had a molecular ion at $\mathrm{m} / \mathrm{z} 160$, again exhibiting loss of hydrogen (base ion at $m / z 159$ ), and losses of 15 (leading to the ion at $m / z 145), 29(m / z ~ 131)$, and $56(m / z 104)$ mass units. The spectrum appeared to be similar, but not fully consistent, with reported spectra of anabaseine (a nicotinerelated tobacco nicotinoid) from the literature (e.g., Wheeler et al., 1981). However, a comparison of mass spectral fragmentation and retention times to an authentic sample of anabaseine [3,4,5,6-tetrahydro-2,3'-bipyridine] showed full correspondence.

Minor Components On the basis of mass spectral fragmentation patterns of components $\mathrm{B}$ and $\mathrm{C}$, two further nicotinic alkaloids were indicated, both showing mass spectra similar to that of nicotine: Component B appeared 


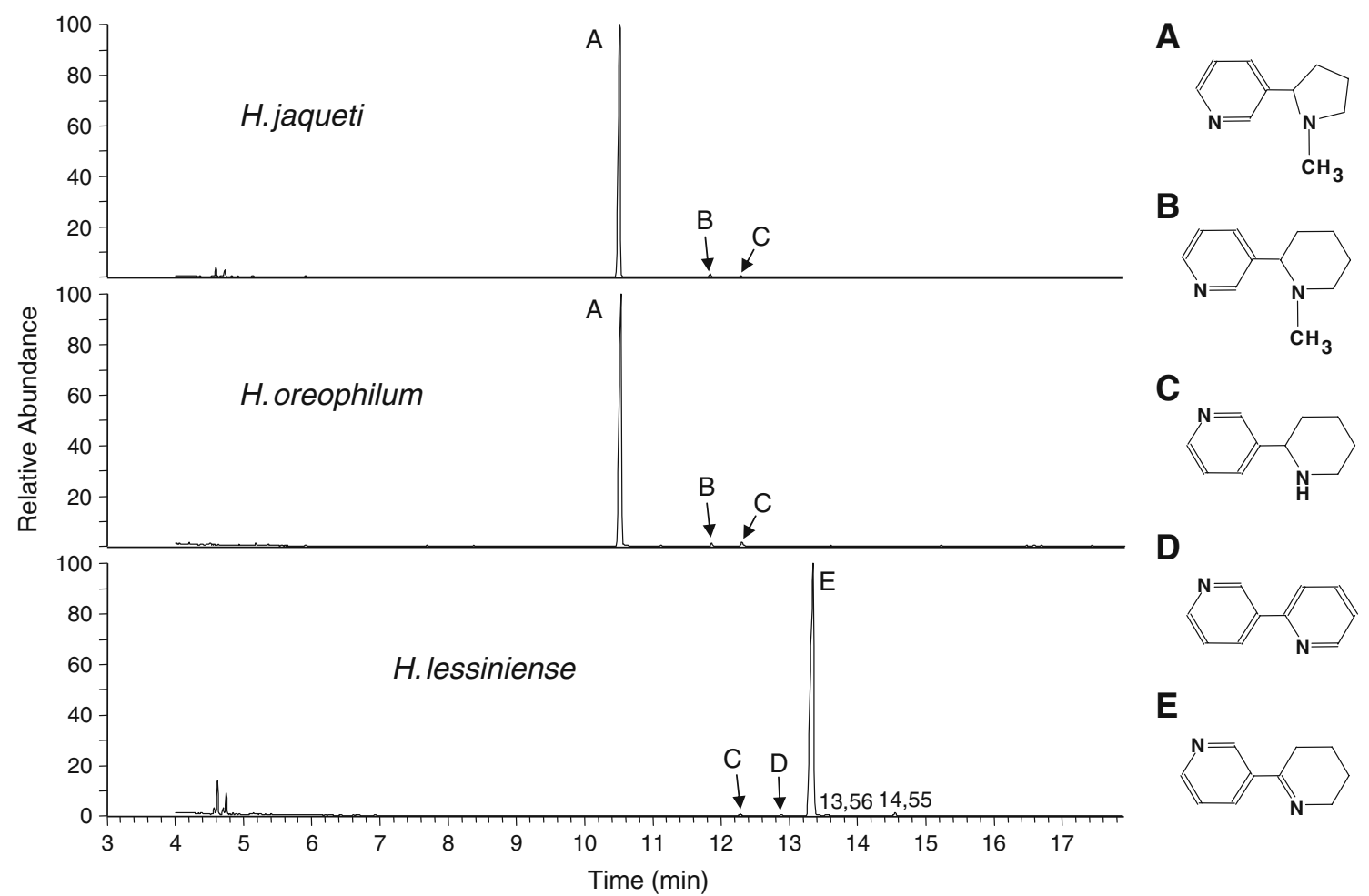

Fig. 1 Chemical profiles of scent gland secretions in three species of Holoscotolemon. Compound A [nicotine], compound B [3-(1-methyl2-piperidinyl)-pyridine], compound $\mathrm{C}$ [anabasine], compound D [2,3'bipyridyl], compound $\mathrm{E}$ [anabaseine]. ${ }^{*}$ Compounds at RT $=13.56 \mathrm{~min}$

to be a higher homolog to nicotine with $\mathrm{M}^{+}$at $\mathrm{m} / z 176$ and a base ion at $m / z 98$, suggesting a piperidine-structure instead of the pyrrolidine-ring. The compound was tentatively identified as 3-(1-methyl-2-piperidinyl)-pyridine by mass spectral comparisons to literature, and to spectra from the NIST-library. The mass spectral fragmentation of component $\mathrm{C}$ differed from that of nicotine mainly in the presence of prominent twin ions at $\mathrm{m} / \mathrm{z} 105$ and $\mathrm{m} / \mathrm{z} 106$, being characteristic of anabasine $[=3-(2-$ piperidinyl)-pyridine]. The compound was identified by and RT=14.55 min were found inconsistently in extracts of Holoscotolemon lessiniense, and possibly represent isomeric, not fully characterized pyridines with a molecular weight of $M=174$

comparisons of spectra and retention times with an authentic sample of anabasine. Only the mass spectrum of component $\mathrm{D}$ was clearly different from all other spectra, although again showing an intense molecular ion at $\mathrm{m} / z 156$ (base ion) along with loss of hydrogen $(\mathrm{m} / \mathrm{z}$ 155). The isotopic $\mathrm{M}+1$-ion (about $12 \%$ relative intensity) still indicated the presence of 10 carbon and 2 nitrogen atoms, suggesting a molecular formula of $\mathrm{C}_{10} \mathrm{H}_{8} \mathrm{~N}_{2}$, and thus corresponding to the fully aromatic homolog of anabasine and anabaseine, 2,3'-bipyridyl [2-(3-pyridinyl) pyridine].

Table 2 Gas chromatographic and mass spectral data to components from extracts of Holoscotolemon lessiniense, H. oreophilum, and H. jaqueti

\begin{tabular}{|c|c|c|c|}
\hline Peak & $\begin{array}{l}\text { Retention } \\
\text { time (min) }\end{array}$ & EI-fragmentation $(\mathrm{m} / \mathrm{z})$ & Identified as \\
\hline A & 10.54 & $\begin{array}{l}162\left(\mathrm{M}^{+}, 49\right), 161(46), 133(79), 119(24), 118(16), 92(23), 84(100), \\
\quad 65(21), 51(22), 42(61)\end{array}$ & $\begin{array}{l}\text { nicotine }=(S)-3-(1-\text { methyl-2- } \\
\text { pyrrolidinyl)-pyridine }\end{array}$ \\
\hline B & 11.85 & $176\left(\mathrm{M}^{+}, 12\right), 175(7), 147(7), 133(9), 119(24), 98(100), 42(28)$ & 3-(1-methyl-2-piperidinyl)-pyridine ${ }^{\mathrm{a}}$ \\
\hline $\mathrm{C}$ & 12.29 & $\begin{array}{l}162\left(\mathrm{M}^{+}, 26\right), 161(23), 133(45), 119(45), 106(49), 105(60), 92(19), \\
84(100), 80(22), 78(20), 57(29), 51(28), 41(38)\end{array}$ & anabasine $=3$-(2-piperidinyl)-pyridine \\
\hline $\mathrm{D}$ & 12.89 & $\begin{array}{l}157(12), 156\left(\mathrm{M}^{+}, 100\right), 155(71), 130(20), 128(12), 104(7), 79 \text { (13), } \\
\quad 78(22), 51(13)\end{array}$ & $\begin{array}{l}\text { 2,3'-bipyridinyl }=2-(3 \text {-pyridinyl)- } \\
\text { pyridine }^{\mathrm{a}}\end{array}$ \\
\hline $\mathrm{E}$ & 13.35 & $\begin{array}{l}161(12), 160\left(\mathrm{M}^{+}, 97\right), 159(100), 145(46), 132(14), 131(79), 118(8), \\
105(44), 104(76), 78(27), 77(29), 51(36), 41(29)\end{array}$ & $\begin{array}{l}\text { anabaseine }=3,4,4,6 \text {-tetrahydro-2, } 3^{\prime} \text { - } \\
\text { bipyridine }\end{array}$ \\
\hline
\end{tabular}

${ }^{a}$ Tentatively identified on the basis of mass spectral data 
Subsequent mass spectral comparisons confirmed a mass spectral fragmentation pattern indistinguishable from spectra of authentic 2,3'-bipyridyl from literature and from the NIST-library.

Extract Profiles Two different extract patterns were clearly distinguished: (1) Nicotine-rich and (2) anabaseine-rich extracts. The extracts of Holoscotolemon oreophilum and $H$. jaqueti were dominated by compound A (nicotine: $>97 \%$ of the secretion, based on calculation of peak areas, see also Table 2 and Fig. 1). Components B (3-(1-methyl-2piperidinyl)-pyridine) and $\mathrm{C}$ (anabasine) were found constantly as accompanying minor or trace components (each about $1 \%$ of the secretion). In $H$. lessiniense, anabaseine (compound E) was the major compound in the extracts ( $>95 \%$, see Table 2 and Fig. 1), accompanied by trace amounts of anabasine and 2,3'-bipyridyl (each about 1-3\% of the secretion). In two out of five extracts, two trace components were also found at $\mathrm{RT}=13.56 \mathrm{~min}$ and $14.55 \mathrm{~min}$ (each about 1\% of the secretion), both showing a pyridine-like pattern and a molecular weight of 174 , but both remain unidentified.

It is noteworthy that some individuals did not show any components. In particular, extracts of three specimens (all collected at one locality in Serbia, see Table 1) of H. jaqueti were investigated, and two of these (one female, one juvenile) consistently showed the nicotine-rich composition mentioned above. In the extract of the remaining specimen (a juvenile), no components could be detected. For $H$. lessiniense, we analyzed extracts of five individuals (all female), which were from two different collections (see Table 1): Three extracts (two of collection no. 1, one of collection no. 2) exhibited the anabaseine-rich scent gland profile described above. No components could be extracted from two other specimens (from collection no. 1). For the largest species of the genus, $H$. oreophilum, only two individuals (one male, one female) were available to us, both of which discharged large amounts of nicotine. Absolute amounts of secretions were determined for $H$. oreophilum, and were calculated to be about $15 \mu \mathrm{g}$ nicotine per individual $(11.8 \mu \mathrm{g}$ measured for one specimen, $16 \mu \mathrm{g}$ for the other specimen).

Thus, only for $H$. oreophilum (nicotine-rich), could male and female extracts be compared, showing no differences. For H. jaqueti (nicotine-rich) and H. lessiniense (anabaseine-rich), only females and juveniles (subadult females) were available; between subadults and adults, no differences were recognized.

Holoscotolemon unicolor Contrasting the results obtained from $H$. jaqueti, $H$. oreophilum, and $H$. lessiniense, no components were detected in any of the nine extracts from adults of $H$. unicolor. This was surprising since these specimens were from several different collection sites in Austria and were collected at different times of the year (see Table 1). Scent glands in H. unicolor, as well as openings (ozopores) appeared to be as well developed as in the other Holoscotolemon species (Fig. 2). However, in one extract of an early-instar juvenile, traces of three nitrogen-containing compounds were detected (not shown), whereas extracts of 11 other juveniles did not show any compounds. The trace components in the single juvenile extract were tentatively identified as dimethyl-isoalkylpyrazines by mass spectral comparisons to literature, and to spectra from the NISTlibrary (compound 1: a dimethyl-isobutylpyrazine, $\mathrm{M}^{+}$at $\mathrm{m} / \mathrm{z}$ 164; compounds 2 and 3 : isomeric dimethylisopentylpyrazines, $\mathbf{M}^{+}$at $m / z$ 178).

\section{Discussion}

Origin of Extract Components We assume that the compounds found in the whole body extracts of Holoscotolemon herein investigated are from the scent glands of these species. This view is based on several facts, and on corroborating evidence from previous studies. First, scent glands are the only glandular structures capable of producing such amounts of secretions; they are large and well developed in all species of the genus Holoscotolemon. Corroborative evidence for the scent gland origin of extract components comes from extraction-attempts of individuals with obviously depleted gland reservoirs. We assume that we may have examined many "empty" specimens, as indicated by the lack of any compound in the gas chromatograms of extracts. From previous investigations, we know that depletion of gland reservoirs can be a rapid process, mainly depending on external irritation stimuli. Refill of glandular reservoirs is slow; according to Holmberg (1970), this process takes a few days in phalangiids. We do not know anything about the refilling capability in species of Holoscotolemon. In our study, the relation of specimens with well-filled gland reservoirs to specimens with depleted reservoirs was about 1:1 for $H$. jaqueti and $H$. lessiniense. Glandular depletion may be explained by irritating stimuli in the course of collection and transport. Absolute amounts of secretion, as shown for nicotine in extracts of $H$. oreophilum, were calculated to be about $15 \mu \mathrm{g}$ per individual. Such amounts correspond to a volume of $15 \mathrm{nl}$ of nicotine (which is a liquid with a density of $1.01 \mathrm{~g} / \mathrm{ml}$ at room temperature), and hence to two hypothetical spherical "droplets" of about $130 \mu \mathrm{m}$ in diameter. Moreover, droplets of that size would be consistent with the expected dimension and filling capacity of glandular reservoirs in Holoscotolemon, at least if glandular dimensions in other opilionids of comparable 
Fig. 2 Position and morphology of ozopores in species of genus Holoscotolemon. Arrows point to ozopores that are located near dorsally to coxae II. a Holoscotolemon unicolor, and b detail of ozopore. c Holoscotolemon oreophilum; d Holoscotolemon lessiniense; $\mathbf{e}$ and $\mathbf{f}$ details of left ozopore in $\mathrm{Hol}$ oscotolemon jaqueti
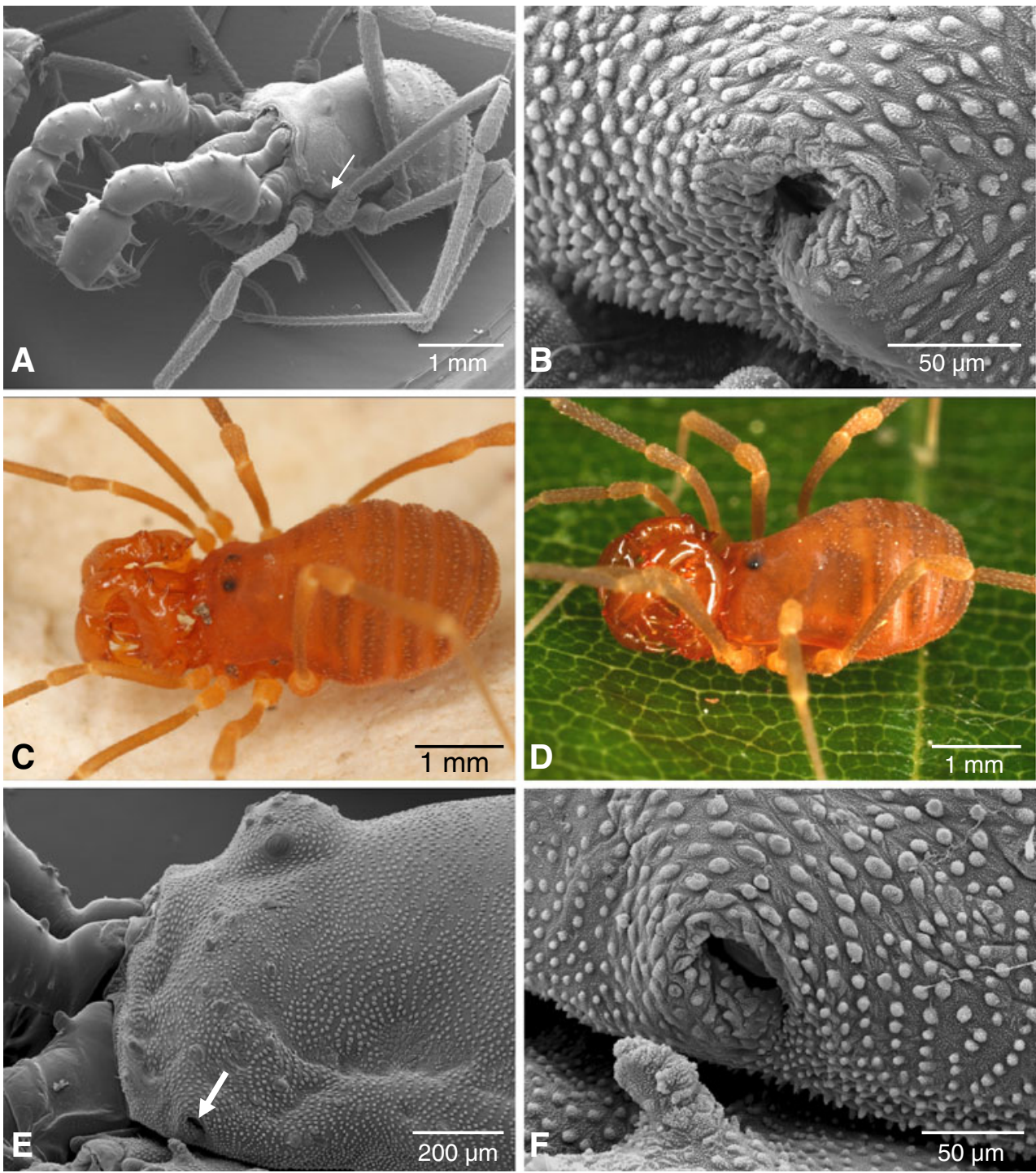

size are considered (e.g., Juberthie, 1976; Schaider and Raspotnig, 2009).

In general, the whole body extraction-method is widely used and commonly accepted for the assessment of exocrine products in small arthropods that are too tiny to sample or dab their secretions directly from the gland orifices. The method has been standardized for investigations of exocrine glandular products in oribatid and astigmatid mites over many years (Sakata and Norton, 2001; Raspotnig et al., 2001, 2008), and also has been used to assess scent gland exudates of opilionids of different groups (Raspotnig et al., 2005, 2010; Jones et al., 2009; Shear et al. 2010a,b). For instance, in sironids (Cyphophthalmi) direct sampling of secretions from ozopores leads to the same chemical results as working with hexane whole body extracts (Raspotnig et al., 2005).

Nicotine and Anabaseine In general, tobacco alkaloids are unusual components in arthropod exocrine secretions.
Nicotine is known only from Sclerobunus robustus (a travunioid laniatorean) (www.pherobase.com). Anabaseine, on the other hand, is new for scent gland secretions of Opiliones. However, this compound is a nicotine-derived alkaloid. Nicotine is a defensive neurotoxin of some plants, and anabaseine is a neurotoxin from nemertine worms that use it for paralyzing prey and possibly for deterring predators (Kem, 1971; Kem et al., 1971, 1976). Regarding arthropods, anabaseine-rich secretions appear to be rare. One example, however, is the poison glands of certain myrmicine ants (Wheeler et al., 1981; Leclercq et al., 2001; Co et al., 2003), where anabaseine also may act as a part of the trail pheromone (Attygalle et al., 1998). In certain hymenopterans, anabaseine is found as a by-product in anabasine-rich secretions (Co et al., 2003; Cruz-Lopez et al., 2006). Anabaseine is remarkable for exhibiting striking neurotoxic effects by interacting with nicotinic receptors, and a synthetic anabaseine-derivative has proved to be a 
promising test agent to study and cure cognitive function loss associated with several human diseases (Kem et al., 1997, 2006). To our knowledge, H. lessiniense is the only arthropod species producing an exocrine secretion almost exclusively based on anabaseine. It is further interesting to note that $H$. lessiniense (anabaseine-rich) and $H$. oreophilum (nicotine-rich), both occurring in the Italian Southern Alps and separated by an air-line distance of just $300 \mathrm{~km}$, use differently composed secretions; this might indicate more specific communicative functions of scent gland secretions in cladonychiid harvestmen, in addition to assumingly defensive roles.

Pyridines and Alkyl-pyrazines Three minor components in the Holoscotolemon-secretions were classified as pyridines, chemically close to nicotine and anabaseine. These compounds may represent by-products of the biosynthetic pathways to nicotine and anabaseine, but the possibility of their artificial formation from major compounds in the hot injector of the gas chromatograph cannot be excluded. In fact, small amounts of 2,3'-bipyridyl also could be detected when analyzing an authentic sample of anabasine, calling the scent gland origin of 2,3'-bipyridyl into question. On the other hand, 2,3'-bipyridyl is known to represent a second neurotoxic component in nemertine worms, in addition to anabaseine (Kem et al., 1976), and also occurs in exocrine glands of certain Aphaenogaster and Messor ants (Attygalle et al., 1998; Co et al., 2003). The alkyl-pyrazines detected in the extract of one single juvenile of $H$. unicolor also are widespread exocrine compounds in several species of ants and wasps (Cavill and Houghton, 1974; Borg-Karlson and Tengö, 1980; Wheeler et al., 1982; Tecle et al., 1987; Brophy, 1989; Jones et al., 1998; Morgan et al., 1999). In some cases, alkyl pyrazines seem to accompany alkaloids of the anabasine-type as minor components in exocrine secretions of some hymenopterans (e.g., Cruz-Lopez et al., 2006). However, our preliminary chemical data for $H$. unicolor, deviating from the chemistry of the other three Holoscotolemon species, need further clarification, and we hope to unravel this question in the near future.

Chemosystematics in Genus Holoscotolemon Our study provides an analysis of the scent-gland chemistry of all four Alpine and Carpathian Holoscotolemon species. In this context as well as from a zoogeographical and evolutionary point of view, questions concerning the presently inhabited areas of these species are of interest, particularly with respect to the hypothetical regions where they outlasted the last iceage (Würm). Holoscotolemon unicolor is endemic to the Eastern Alps and, following Holdhaus (1954), Thaler (1966, 1976), and Komposch (2009), is a re-wanderer of long distance, which probably survived the last ice age in "massifs de refuge" of the South-Eastern Alps. Holoscoto- lemon oreophilum and $H$. lessiniense are local endemics of the Southern Alps, and should have survived the Würm iceage in "massifs de refuge" in the areas of their present distribution in the Sea Alps (H. oreophilum) and Monti Lessini (H. lessiniense), respectively. Martens (1978) found no close relationship between $H$. lessiniense and $H$. unicolor, and believed the former species is closer to $H$. oreophilum. Therefore, it is surprising that the available chemical information points toward a high similarity between the most western $(H$. oreophilum) and the most eastern species (H. jaqueti). Thus, tentatively, nicotine may represent a plesiomorphic compound in Holoscotolemon (and possibly also in Travunioidea, see below) while $H$. lessiniense, occurring in an area in between, shows a clearly distinct although related chemistry (i.e., anabaseine-rich), possibly representing the derivative status.

Scent Gland Chemistry in Insidiatores The major part of laniatorean scent gland research has been performed on grassatorean Laniatores, and this strong bias may have contributed to the picture of a typical, rather homogenous, phenolic and benzoquinone-rich "laniatorean chemistry". Phenol- and benzoquinone-rich secretions have been identified from representatives of all grassatorean families hitherto investigated, such as many Gonyleptidae (see Gnaspini and Hara, 2007 and references therein; Hara et al., 2005; Machado and Pomini, 2008; Föttinger et al., 2010), Cosmetidae and Manaosbiidae (Eisner et al., 1971, 1977; Roach et al., 1980), Stygnommatidae (Duffield et al., 1981), Stygnopsidae (Pomini et al., 2010; Shear et al., 2010b), and Phalangodidae (Shear et al., 2010a). Even though components other than phenols and benzoquinones (i.e., some accompanying acyclic compounds and alkyl-dihydro-pyrans) have been found in certain Gonyleptidae (Hara et al., 2005; Rocha et al., 2011), nitrogen-containing compounds or even tobacco alkaloids do not seem to occur in the scent glands of the Grassatores. On the other hand, there is growing evidence that insidiatorean secretions - or at least those of superfamily Travunioidea - are based on a completely different chemistry that relies on nitrogen-containing compounds as major secretory constituents. This idea is corroborated by the pioneering study of Ekpa et al. (1984) who found two nitrogen-containing compounds (ß-dimethylphenylethylamine and nicotine) in the scent gland secretion of Sclerobunus robustus, a travunioid species from both another continent (America) and a second travunioid family (Travuniidae; Kury 2000 onwards). For grouping of "Northern Hemisphere Triaenonychoidea" such as Sclerobunus with Travunioidea see Giribet and Kury (2007). Preliminary chemical results from representatives of travuniids in Europe (unpublished) also indicate consistently that tobacco alkaloids constitute major secretory components in species of Travunia and Abasola (for possible synonymies see Kury 
and Mendes 2007) as well as in the so-far systematically unplaced but travunioid Trojanella (Karaman, 2005). In this respect, nitrogen-containing compounds: (1) may be widespread or even common in the Travunioidea; and, (2) according to the basal phylogenetic position of Travunioidea within Laniatores, these compounds also may represent the ancestral scent gland equipment of laniatoreans.

Opilionid scent gland secretions generally seem to be a promising pool of group- or even species-specific chemical characters, representing an independent set of data of phylogenetic value, in addition to characters from traditional morphology and molecular genetics. The importance of scent gland chemistry for studies of opilionid phylogeny has been emphasized previously (Roach et al., 1980; Duffield et al., 1981), and more recent papers have added to this topic (Raspotnig et al., 2005, 2010; Jones et al., 2009). So far, an evolutionary line may be traced from the naphthoquinoneand acyclic ketone-rich secretions of the Cyphophthalmi to the similarly structured secretions in eupnoid and dyspnoid Palpatores (see introduction), but any evolutionary link to the chemically distinct secretions of Laniatores is still missing. Additionally, within the Laniatores, the "chemical gap" between the alkaloid-rich secretions of the Travunioidea on the one hand and the generally phenol- and benzoquinone-rich chemistry in the Grassatores on the other hand is not yet well explained. In this regard, information on the unknown scent gland chemistry of the "true" Triaenonychoidea (sensu Kury, 2000 onwards) would be important, as this mainly Southern Hemisphere-distributed group of Insidiatores (see Pinto-da-Rocha and Giribet, 2007) may represent the missing link in the chemosystematic puzzle of harvestmen.

Acknowledgements This work was supported by a grant from the Austrian Science Fund (FWF), project number P21819-B16. We thank Dr. Peer Schnitter (Landesamt für Umweltschutz Sachsen-Anhalt, Halle/Saale, Germany) and Dr. Volker Neumann (Lieskau, Germany) for help with collecting in the Italian Alps, Dr. Axel Schönhofer (Institute of Zoology, Johannes Gutenberg-University, Mainz, Germany) for providing some specimens of Holoscotolemon unicolor, and Dr. Edith Stabentheiner (Institute of Plant Sciences, KarlFranzens University, Graz, Austria) for assistance in taking the scanning electron micrographs.

Open Access This article is distributed under the terms of the Creative Commons Attribution Noncommercial License which permits any noncommercial use, distribution, and reproduction in any medium, provided the original author(s) and source are credited.

\section{References}

Attygalle, A. B., Kern, F., Huang, Q., and Meinwald, J. 1998. Trail pheromone of the myrmicine ant Aphaenogaster rudis (Hymenoptera: Formicidae). Naturwissenschaften 85:38-41.
Blum, M. S., and Edgar, A. L. 1971. 4-Methyl-3-heptanone: Identification and role in opilionid exocrine secretions. Insect Biochem. 1:181-188.

Borg-Karlson, A.-K., and Tengö, J. 1980. Pyrazines as marking volatiles in philanthine and nyssonine wasps (Hymenoptera: Sphecidae). J. Chem. Ecol. 6:827-835.

BRopHY, J. J. 1989. Pyrazines obtained from insects: Their source, identification, synthesis, and function, pp. 221-273, in A.-U. Rahman (ed.). Studies in Natural Products Chemistry, Vol. 5, Structure Elucidation, Part B. Elsevier, Amsterdam.

Cavill, G. W. K., and Houghton, E. 1974. Some pyrazine derivatives from the Argentine ant, Iridomyrmex humilis. Austr. J. Chem. 27:879-889.

Co, J. E., Jones, T. H., Hefetz, A., Tinault, A., and Snelling, R. R. 2003. The comparative exocrine chemistry of nine Old World species of Messor (Formicidae: Myrmicinae). Biochem. Syst. Ecol. 31:367-373.

CORTI, E. 1905. Faune de la Roumanie (in Jaquet, M.). Bull. Soc. Bucarest 14:204-226.

Cruz-Lopez, L., Jackson, B. D., Hefetz, A., and Morgan, D. E. 2006. Alkaloids in the venom of Messor ants. Biochem. Syst. Ecol. 34:199-204.

DufField, A. M., BudziKIEwICZ, H., and DJerassi, C. 1965. Mass spectrometry in structural and stereochemical problems. LXXII. A study of the fragmentation processes of some tobacco alkaloids. J. Am. Chem. Soc. 87:2926-2932.

DufField, R. M., Olubajo, O., Wheeler, J. W., and Shear, W. A. 1981. Alkylphenols in the defensive secretion of the Neartic opilionid, Stygnomma spinifera. J. Chem. Ecol. 7:445-452.

Eisner, T., Kluge, A. F., Carrel, J. E., and Meinwald, J. 1971. Defense of Phalangid: Liquid repellent administered by leg dabbing. Science 173:650-652.

Eisner, T., Jones, T. H., Hicks, K., Silberglied, R. E., and MEINWALD, J. 1977. Quinones and phenols in the defensive secretions of Neotropical opilionids. J. Chem. Ecol. 3:321329.

EISNER, T., Rossini, C., and EISNER, M. 2004. Chemical defense of an opilionid (Acanthopachylus aculeatus). J. Exp. Biol. 207:13131321.

EkPa, O., Wheeler, J.W., Cokendolpher, J. C., and Duffield, R. M. 1984. N,N-dimethyl- $\beta$-phenylethylamine and bornyl esters from the harvestman Sclerobunus robustus (Arachnida: Opiliones). Tetrahedron Lett. 25:1315-1318.

EKPA, O., WheEler, J. W., COKENDOlPher, J. C., and Duffield, R. M. 1985. Ketones and alcohols in the defensive secretion of Leiobunum townsendi Weed and a review of the known exocrine secretions of Palpatores (Arachnida: Opiliones). Comp. Biochem. Physiol. 81B:555-557.

Estable, C., Ardao, M. I., Brasil, N. P., and Fieser, L. F. 1955. Gonyleptidine. J. Amer. Chem. Soc. 77:4942.

FIESER, L. F., and ARDAO, M. I. 1956. Investigations of the chemical nature of gonyleptidine. J. Am. Chem. Soc. 78:774-881.

Föttinger, P., Acosta, L. E., Leis, H. J., and Raspotnig, G. 2010. Benzoquinone-rich exudates from the harvestman Pachylus paessleri (Opiliones: Gonyleptidae: Pachylinae). J. Arachnol. 38:584-587.

GiRIBET, G., and KURY, A. B. 2007. Phylogeny and biogeography, pp.62-87, in R. Pinto-da-Rocha, G. Machado, and G. Giribet (eds.). Harvestmen - The Biology of Opiliones. Harvard University Press, Cambridge.

GNASPINI, P., and HARA, M. R. 2007. Defense mechanisms, pp. 374 399, in R. Pinto-da-Rocha, G. Machado, and G. Giribet (eds). Harvestmen - The Biology of Opiliones. Harvard University Press, Cambridge.

Hara, M. R., Cavalheiro, A. J., Gnaspini, P., and Santos, D. Y. A. C. 2005. A comparative analysis of the chemical nature of 
defensive secretions of Gonyleptidae (Arachnida: Opiliones: Laniatores). Biochem. Syst. Ecol. 33:1210-1225.

Holdhaus, K. 1954. Die Spuren der Eiszeit in der Tierwelt Europas. Abh. zool.-bot. Ges. Wien 18:1-493.

HolmBerG, R. G. 1970. The Oodiferous Glands of some Palpatores Phalangida (Opiliones) (Arachnida). M.Sc.Thesis, Saskatoon, University of Saskatchewan (Canada), p. 134.

HolmberG, R. G. 1986. The scent glands of Opiliones: A review of their function, pp. 131-133, in W. G Eberhard, Y. D. Lubin, and B. C. Robinson (eds). Proceedings of the 9th International Congress of Arachnology (Panama 1983), Smithsonian Institution Press, Washington.

Jones, T. H., Conner, W. E., Kluge, A. F., Eisner, T., and MeINWALd, J. 1976. Defensive substances of opilionids. Experientia 32:1234-1235.

Jones, T. H., Meinwald, J., Hicks, K., and Eisner, T. 1977. Characterization and synthesis of volatile compounds from the defensive secretions of some "daddy longlegs" (Arachnida: Opiliones: Leiobunum spp.). Proc. Natl. Acad. Sci. USA 74:419-422.

Jones, T. H., Garaffo, H. M., Blum, M. S., Everett, D. M., Hastings, H., and WARE, A.B. 1998. Elucidation of dimethylalkylpyrazines from the ant Streblognathus aethiopicus by GCFTIR. J. Chem. Ecol. 24:125-134.

Jones, H. J., Shear, W. A., and Giribet, G. 2009. The chemical defences of a stylocellid (Arachnida, Opiliones, Stylocellidae) from Sulawesi with comparisons to other Cyphophthalmi. J. Arachnol. 37:147-150.

JuberthIE, C. 1976. Chemical defence in soil Opiliones. Rev. Ecol. Biol. Sol 13:155-160.

KARAMAN, I. 2005. Trojanella serbica gen. n., sp. n., a remarkable new troglobitic travunioid (Opiliones, Laniatores, Travunioidea). Rev. Suisse Zool. 112:439-455.

KEM, W. R. 1971. A study on the occurrence of anabaseine in Paranemertes and other nemertines. Toxicon 9:23-32.

KeM, W. R., AвBOtT, B. C., and CoAtes, R. M. 1971. Isolation and structure of a hoplonemertine toxin. Toxicon 9:15-22.

KEM, W. R. SCOTT, K. N., and DUNCAN, J. H. 1976. Hoplonemertine worms - a new source of pyridine neurotoxins. Experientia $32: 684-686$

KeM, W. R., MAHniR, V. M., PAPKe, R. L., and LingLe, C. J. 1997. Anabaseine is a potent agonist on muscle and neuronal alphabungarotoxin-sensitive nicotinic receptors. J. Pharmacol. Exp. Ther. 283: 979-992.

Kem, W., Scoti, F., Wildeboer, K., LeFrancois, S., MacDougall, K., WeI, D.-Q., ChOU, K.-C., and ARIAS, H. R. 2006. The nemertine toxin anabaseine and its derivative DMXBA (GTS21): Chemical and pharmacological properties. Mar. Drugs $4: 255-273$.

KoMPOSCH, C. 2009. Weberknechte (Opiliones), pp. 476-496, in W. Rabitsch and F. Essl (eds). Endemiten: Kostbarkeiten in Österreichs Tier- und Pflanzenwelt, Naturwissenschaftlicher Verlag für Kärnten und Umweltbundesamt, Vienna.

KURY, A. B. 2000 onwards. Classification of Opiliones. Museu Nacional/UFRJ website. Online at: http://www.museunacional. ufrj.br/mndi/Aracnologia/Opiliones.html; status: April 292011

Kury, A. B., and Mendes, A. C. 2007. Taxonomic status of the European genera of Travuniidae (Arachnida, Opiliones, Laniatores). Mun. Ent. Zool. 2:1-14.

LeclercQ, S., Charles, S., Daloze, D., Breakman, J.-C., Aron, S., and PAsteEls, J. M. 2001. Absolute configuration of anabasine from Messor and Aphaenogaster ants. J. Chem. Ecol. 27:945-952.

MACHADO, G., and POMINI, M. 2008. Chemical and behavioral defenses of the neotropical harvestman Camarana flavipalpi (Arachnida: Opiliones). Biochem. Syst. Ecol. 36:369-376.
Machado, G., Bonato, V., and Oliveira, P. S. 2002. Alarm communication: A new function for the scent gland secretion in harvestmen (Arachnida: Opiliones). Naturwissenschaften $89: 357-360$.

MARTENS, J. 1978. Spinnentiere, Arachnida. Weberknechte, Opiliones. Die Tierwelt Deutschlands, 64. Teil, Gustav Fischer Verlag, Jena, p. 449.

Meinwald, J., Kluge, A. F., Carrel, J. E., and Eisner, T. 1971. Acyclic ketones in the defensive secretion of a "daddy longlegs" (Leiobunum vittatum). Proc. Natl. Acad. Sci. USA 68:1467-1468.

Morgan, E. D., Do Nascimento, R. R., Keegans, S. J., and BILlEN, J. 1999. Comparative study of the mandibular gland secretions of workers of ponerine ants. J. Chem. Ecol. 25:13951409.

PINTO-DA-RochA, R., and GIRIBET, G. 2007. Taxonomy, pp. 88-246, in R. Pinto-da-Rocha, G. Machado, and G. Giribet (eds.). Harvestmen - The Biology of Opiliones, Harvard University Press, Cambridge.

Pomini, A. M., Machado, G., Pinto-Da-Rocha, R., MaciasORdONEZ, R., and MARSAIOLI, A. J. 2010. Lines of defense in the harvestman Hoplobunus mexicanus (Arachnida: Opiliones): Aposematism, stridulation, thanatosis, and irritant chemicals. Biochem. Syst. Ecol. 38: 300-308.

Raspotnig, G., Schuster, R., KrisPer, G., Fauler, G., and Leis, H. J. 2001. Chemistry of the oil gland secretion of Collohmannia gigantea (Acari, Oribatida). Exp. Appl. Acarol. 25:933-946.

Raspotnig, G., FAUler, G., LeIS, M., and LeIS, H. J. 2005. Chemical profiles of scent gland secretions in the cyphophthalmid opilionid harvestmen, Siro duricorius and S. exilis. J. Chem. Ecol. 31:1353-1368.

Raspotnig, G., Kaiser, R., Stabentheiner, E., and Leis, H. J. 2008. Chrysomelidial in the opisthonotal glands of the oribatid mite, Oribotritia berlesei. J. Chem. Ecol. 34:1081-1088.

Raspotnig, G., Leutgeb, V., Schaider, M., and Komposch, C. 2010. Naphthoquinones and anthraquinones from scent glands of a dyspnoid harvestman, Paranemastoma quadripunctatum. J. Chem. Ecol. 36:158-162.

RoACH, B., EISNER, T., and MEINWALD, J. 1980. Defensive substances in opilionids. J. Chem. Ecol. 6:511-516.

Rocha, D. F. O., Hamilton, K., Gonçalves, C. C. S., Machado, G., and MARSAIOLI, A. J. 2011. 6-Alkyl-3,4-dihydro-2H-pyrans: Chemical secretion compounds in neotropical harvestmen. J. Nat. Prod. 74:658-663.

Roewer, C. F. 1915. 106 neue Opilioniden. Arch. Naturgesch. 81:1152.

SAKATA, T., and NORTON, R. A. 2001. Opisthonotal gland chemistry of early-derivative oribatid mites (Acari) and its relevance to systematic relationships of Astigmata. Int. J. Acarol. 27:281291.

SCHAIDER, M., and RASPOTNIG, G. 2009. Unusual organization of scent glands in Trogulus tricarinatus (Opiliones, Trogulidae): Evidence for a non-defensive role. J. Arachnol. 37:78-83.

Shear, W. A., Jones, T. H., and Snyder, A. J. 2010a. Chemical defense of phalangodid harvestmen: Bishopella laciniosa (Crosby \& Bishop) and Texella bifurcata (Briggs) produce 2methyl-5-ethylphenol (Opiliones: Grassatores: Phalangodidae). Bull. Br. Arachnol. Soc. 15: 27-28.

Shear, W. A., SnYder, A. J., Jones, T. H., Garaffo, H. M., and ANDRIAMAharavo, N. R. 2010b. The chemical defense of the Texas cave harvestman Chinquipellobunus madlae: First report on the family Stygnopsidae and on a North American troglobiont harvestman (Opiliones: Gonyleptoidea). J. Arachnol. $38: 126-127$

Tecle, B., Sun, C.-M., Brophy, J. J., and Toia, R. F. 1987. Novel pyrazines from the head of Australian ponerine ant Rhytidoponera metallica. J. Chem. Ecol. 13:1811-1822. 
THALER, K. 1966. Zur Arachnidenfauna der mittleren Ostalpen. Senckenbergiana biol. 47:77-80.

THALER, K. 1976. Endemiten und arktoalpine Arten in der Spinnenfauna der Ostalpen (Arachnida: Araneae). Ent. Germ. 3:135-141.

UBICK, D., and Dunlop, J. A. 2005. On the placement of the Baltic amber harvestman Gonyleptes nemastomoides Koch \& Berendt, 1854 , with notes on the phylogeny of Cladonychiidae (Opiliones, Laniatores, Travunioidea). Mitt. Mus. Nat.kde. Berl., Geowiss. Reihe 8:75-82.
Wheeler, J. W., Olubajo, O., Storm, C. B., and Duffield, R. M. 1981. Anabaseine: Venom alkaloid of Aphaenogaster ants. Science 211:1051-1052.

Wheeler, J. W., Avery, J., Olubajo, O., Shamim, M. T., Storm, C. B., and DUFFIELD, R. M. 1982. Alkylpyrazines from Hymenoptera. Tetrahedron 38:1939-1948.

Wiemer, D. F., Hicks, K., MeInwald, J., and EISNER, T. 1978. Naphthoquinones in the defensive secretion of an opilionid. Experientia 34:969-970. 